\title{
Growth and Yield Performance of Roselle Accessions as Influenced by Intercropping with Maize in the Guinea Savannah Ecology of Ghana
}

\author{
Emmanuel Ayipio $\left(\mathbb{D},{ }^{1}\right.$ Moomin Abu, ${ }^{2}$ Richard Yaw Agyare $\left(\mathbb{D},{ }^{1}\right.$ \\ Dorothy Ageteba Azewongik, ${ }^{2}$ and Samuel Kwame Bonsu' ${ }^{1}$ \\ ${ }^{1}$ CSIR-Savanna Agricultural Research Institute, P.O. Box TL 52, Nyankpala, N/R, Ghana \\ ${ }^{2}$ University for Development Studies, Faculty of Agriculture, Department of Horticulture, P.O. Box 1882, Nyankpala, N/R, Ghana \\ Correspondence should be addressed to Emmanuel Ayipio; emmayipio@gmail.com
}

Received 21 May 2018; Revised 11 August 2018; Accepted 2 September 2018; Published 1 October 2018

Academic Editor: David Clay

Copyright (c) 2018 Emmanuel Ayipio et al. This is an open access article distributed under the Creative Commons Attribution License, which permits unrestricted use, distribution, and reproduction in any medium, provided the original work is properly cited.

\begin{abstract}
Growing roselle with maize is common in Ghana. However, there is little information on whether the choice of accession affects maize/roselle intercrops. Also, there is little information on whether intercropping roselle with maize is beneficial or detrimental to the yields of the crops. A field experiment was conducted for two seasons to assess the growth and yield performance of three roselle accessions as influenced by intercropping with maize and to assess whether maize growth and yield would be influenced upon intercropping with roselle. The roselle accessions were Bissap, Local, and Samadah. Intercropped roselle accessions, their soles, and sole maize were arranged in a randomized complete block design with three replications. Intercrop performance was determined using area $\times$ time equivalence ratio (ATER) and competitive ratio (CR). The results showed significant differences in roselle accessions for growth and yield performance. Local outperformed the other accessions in both growth and yield attributes. Roselle calyx and shoot yields were significantly higher in intercrops than in soles. Maize growth and yield were not significantly affected by intercropping with roselle, but maize yield attributes differed between seasons. The ATERs were 1.99, 2.18, and 2.49 for Samadah, Bissap, and Local, respectively, indicating that there was productive use of space and time for intercropping. The CR ranged from 1.03 to $1.17,0.96$ to 1.09 , and 1.12 to 1.25 for stem diameter, number of leaves per plant, and plant height, respectively. The study showed that the choice of accession did not affect the intercrop performance. It also showed that intercropping roselle with maize is beneficial to roselle without compromising the yield of maize.
\end{abstract}

\section{Introduction}

Roselle (Hibiscus sabdariffa L.) is an annual herbaceous shrub of the family Malvaceae [1]. Young succulent leaves of roselle are eaten in various forms as they contain nutrients such as phosphorus, calcium, magnesium, and potassium [2]. The fleshy calyces of the plant are used in various countries in Africa and the Caribbean as food or food ingredient in jellies, syrups, beverages, puddings, cakes, and wines [3]. Roselle serves as a relish that accompanies foods such as a popular northern Ghanaian food called "Touzaafi"(TZ) which is a thick or solidified porridge prepared from maize meal. A strong fiber called hemp is obtained from the stem which is used for various household purposes including making sackcloth, twine, and cord [4]. In northern Ghanaian homes, the dry stems are a source of fuel for cooking. The seed contains a substantial amount of oil that resembles cotton seed oil [5] and is found to have high antioxidant capacity and strong radical-scavenging activity [6].

Cereal cultivation predominates the agricultural landscape of Ghana. In such areas, intercropping offers an economically sustainable way of producing vegetables like roselle which is classified among underutilized crops [7]. Maize-based intercropping systems are proven to have yield 
advantages over sole cropping by optimizing especially the use of light [8-10] which translates into yield for both crops. Many benefits of intercropping have been reported in the literature $[11,12]$. In addition to these, intercropping vegetables with cereals offers a sustainable way of cultivating vegetables [13].

Growing roselle with maize is a common practice in Ghana. However, when this is done, roselle is usually either planted around the maize farm or spot planted throughout the farm. This practice does not yield the maximum benefit of intercropping. Also, there is little information on whether planting maize with roselle affects maize yields or is beneficial to roselle in Ghana. In addition, there is no information on whether the choice of accession affects maize/roselle intercrops. The objective of the study was to test and identify roselle accession(s) whose yield would increase or be maintained when intercropped with maize without negative yield implications on the maize crop.

\section{Materials and Methods}

2.1. Experimental Site. A field experiment was conducted for two seasons: in 2016 at Faculty of Agriculture, University for Development Studies, and in 2017 at Savanna Agricultural Research Institute of the Council for Scientific and Industrial Research, Ghana. Both institutions are located in Nyankpala in the northern Guinea savannah ecological zone of Ghana at longitude $0^{\circ} 98^{\prime} \mathrm{W}$ and latitude $9^{\circ} 4^{\prime} \mathrm{N}$ and at an altitude of $183 \mathrm{~m}$ above the sea level [14]. The chemical properties of the soil for both experimental sites are presented in Table 1. The area experiences a unimodal rainfall with annual rainfall ranging between $1000 \mathrm{~mm}$ and $1200 \mathrm{~mm}$ from May to October but sporadic during other times of the year. The monthly mean temperature is $22^{\circ} \mathrm{C}$ in the rainy season and $34^{\circ} \mathrm{C}$ in the dry season [14]. The mean monthly rainfall, minimum and maximum temperatures, and relative humidity data covering the experimental periods of each year are presented in Table 2.

2.2. Plant Materials. The maize variety wang-dataa was the main crop. It matures in 90 days. It was obtained from the Savanna Agriculture Research Institute (CSIR-SARI). Three roselle accessions were obtained from WorldVeg through CSIR-SARI. The roselle accessions were Bissap with dark red calyces and leaves, Local with light green calyces and leaves, and Samadah with greenish red leaves and light red calyces [15]. Bissap has an average height of $132 \mathrm{~cm}$, a leaf length-towidth ratio of about 1.3 , and a short true stem with multiple main branches. Local can grow up to an average height of $157 \mathrm{~cm}$; it has a leaf length-to-width ratio of about 1.0 and a long main stem with many primary and secondary branches. Samadah can reach an average height of $121 \mathrm{~cm}$ with a leaf length-to-width ratio of 0.8 [15].

2.3. Experimental Design. The experiment was laid out in a randomized complete block design (RCBD) with three replications in both seasons. A plot measured $4 \mathrm{~m} \times 3 \mathrm{~m}$ in 2016 and $5 \mathrm{~m} \times 4.5 \mathrm{~m}$ in 2017. Differences in plot sizes were
TABLE 1: Chemical properties of soil at experimental sites.

\begin{tabular}{lccccc}
\hline Location (season) & $\mathrm{pH}$ & \% OC & $\% \mathrm{~N}$ & $\mathrm{mg} / \mathrm{kg} \cdot \mathrm{P}$ & $\mathrm{mg} / \mathrm{kg} \cdot \mathrm{K}$ \\
\hline CSIR-SARI (2017) & 5.54 & 0.43 & 0.04 & 10.55 & 52.51 \\
UDS (2016) & 5.80 & 0.39 & 0.03 & 4.90 & 46.30 \\
\hline
\end{tabular}

Source: CSIR-SARI Plant and Soil Analytical Laboratory.

due to seed availability in each year. Replications were separated by a distance of $1.5 \mathrm{~m}$, while plots were separated by a $1 \mathrm{~m}$ alley. The treatments were as follows: (1) sole maize (M); (2) sole roselle Local, designated as A1; (3) sole roselle Bissap, designated as A2; (4) sole roselle Samadah, designated as A3; (5) A1 intercropped with maize (A1M); (6) A2 intercropped with maize (A2M); and (7) A3 intercropped with maize (A3M).

2.4. Land Preparation, Sowing, and Crop Management. Experimental fields were ploughed and harrowed after the first stable rains. Seeds of both crops were sown on 6 August 2016 and 5 July 2017 at a rate of 4 seeds per hole for both crops and later thinned to 2 plants per hill for maize and one plant per hill for roselle at 11 days after planting (DAP). In both years' trials, an interrow spacing of $0.75 \mathrm{~m}$ was used for both maize and roselle and an intrarow spacing of $0.4 \mathrm{~m}$ was used for maize and $0.5 \mathrm{~m}$ was used for roselle. Plant density was 4 plants $\cdot \mathrm{m}^{-2}$ ( 48 plants/plot) for sole maize, 3 plants $\cdot \mathrm{m}^{-2}$ (36 plants/plot) for sole roselle, 2 plants $\mathrm{m}^{-2}$ (24 plants/plot) for intercrop maize, and 1 plant $\mathrm{m}^{-2}$ (16 plants/plot) for intercrop roselle.

Fertilizer (NPK) was spot applied to both crops at a rate of $60 \mathrm{~kg} \cdot \mathrm{N} \cdot \mathrm{ha}^{-1}, 40 \mathrm{~kg} \cdot \mathrm{P}_{2} \mathrm{O}_{5} \cdot \mathrm{ha}^{-1}$, and $40 \mathrm{~kg} \cdot \mathrm{K}_{2} \mathrm{O} \cdot \mathrm{ha}^{-1}$ based on the recommendation for both crops. The $\mathrm{N}$ was split applied. Weeds were removed as and when necessary with the aid of a hand hoe.

2.5. Data Collection. Data were collected on growth and yield attributes in both years' trials. Sampling was based on the middle rows in both intercropping and sole cropping for both seasons. Growth measurements were taken on 4 plants in 2016 and 6 plants in the 2017 cropping season. In 2017, there were more plants to sample from due to the larger plot size. Plant height $(\mathrm{cm})$ was measured from the soil level to the tip of the latest apical bud. Number of leaves per plant was determined by counting all the leaves of the sampled plants and then obtaining the mean number of leaves per plant for a particular treatment. Stem diameter $(\mathrm{cm})$ was measured using a GlowGeek digital caliper (Shenzhen YunYuan Technology Co., Ltd, China) at a constant height of $10 \mathrm{~mm}$ from the soil level for both crops. Samples were separated in various aboveground components of shoot, calyx, and seed for roselle and stalk, cob, and grain for maize. Fresh weights were taken at harvest by measuring gravimetrically using a sensitive scale (KERN \& SOHN GmbH, Balingen, Germany) and then left to shade-dry and weighed till a constant weight was obtained. Yields are expressed in t/ha. The weight of thousand seeds for roselle and one hundred seeds for maize were determined gravimetrically. Attributes such as calyx and grain yield fractions were then 
TABLE 2: Meteorological data recorded during the experimental period (2016/2017).

\begin{tabular}{|c|c|c|c|c|c|}
\hline & \multirow{2}{*}{ Rainfall (mm) } & \multicolumn{2}{|c|}{ Temperature $\left({ }^{\circ} \mathrm{C}\right)$} & \multicolumn{2}{|c|}{ Rel. Humidity (\%) } \\
\hline & & Minimum & Maximum & Minimum & Maximum \\
\hline \multicolumn{6}{|l|}{2016} \\
\hline May & 12.60 & 26.37 & 34.74 & 54.35 & 85.42 \\
\hline June & 11.99 & 25.02 & 33.05 & 58.90 & 89.07 \\
\hline July & 32.91 & 23.66 & 30.50 & 72.19 & 93.45 \\
\hline August & 8.13 & 21.94 & 31.67 & 74.06 & 92.68 \\
\hline September & 13.69 & 21.28 & 31.92 & 72.97 & 93.73 \\
\hline October & 7.98 & 21.81 & 34.37 & 63.71 & 92.23 \\
\hline November & Nil & 22.76 & 37.37 & 40.93 & 83.10 \\
\hline December & 43.7 & 20.68 & 37.65 & 28.55 & 64.26 \\
\hline \multicolumn{6}{|l|}{2017} \\
\hline May & 5.90 & 25.86 & 36.25 & 52.19 & 83.29 \\
\hline June & 16.99 & 24.67 & 32.80 & 66.93 & 92.43 \\
\hline July & 30.08 & 23.53 & 30.15 & 73.74 & 94.13 \\
\hline August & 10.91 & 23.43 & 29.33 & 73.68 & 94.39 \\
\hline September & 13.20 & 23.54 & 30.27 & 72.20 & 94.97 \\
\hline October & 5.76 & 23.65 & 32.53 & 59.35 & 90.55 \\
\hline November & 14.20 & 23.41 & 35.64 & 41.03 & 82.47 \\
\hline December & Nil & 21.13 & 35.63 & 20.58 & 49.58 \\
\hline
\end{tabular}

Source: CSIR-SARI Meteorological Services, Nyankpala.

estimated. Total dry biomass was a summation of the weights of the aboveground components.

2.6. Intercrop Performance. Intercrop performance was measured using the area $\times$ time equivalence ratio (ATER), competitive ratio (CR), and percentage land saved (PLS). These are defined below.

(a) Area $\times$ time equivalence ratio (ATER): area $\times$ time equivalence ratio was calculated using the following formula:

$$
\operatorname{ATER}=\frac{([\mathrm{Yia} / \mathrm{Ysa}] \times \mathrm{ta}+[\mathrm{Yib} / \mathrm{Ysb}] \times \mathrm{tb})}{\mathrm{Tt}},
$$

where Yia and Yib are the intercrop yields; Ysa and Ysb are the yields of the sole crops; ta and tb are the maturity times (duration) of species a and b ( $\mathrm{a}$ in our case is roselle accession and $\mathrm{b}$ is maize); and $\mathrm{Tt}$ is the total time occupied by the intercrop.

(b) Percentage land saved (PLS):

$$
\mathrm{PLS}=\frac{(\mathrm{ATER}-1)}{\mathrm{ATER}} \times 100
$$

(c) Competitive ratio (CR): the concept of competitive ratio was used to estimate the competitiveness for number of leaves per plant, plant height, and stem diameter of the roselle accessions and is given as follows:

$$
\mathrm{CRab}=\frac{(\mathrm{Yia} / \mathrm{Ysa} * \mathrm{Fa})}{(\mathrm{Yib} / \mathrm{Ysb} * \mathrm{Fb})},
$$

where Yia and Yib are the number of leaves, plant height, or stem diameter of species "a" (roselle accessions) and " $b$ " (maize) in intercropping; Ysa and Ysb are the values of the parameter for the species "a" and "b" in sole cropping; and $\mathrm{Fa}$ and $\mathrm{Fb}$ are the proportions of the area occupied by crops in " $a$ " and " $b$ " in the intercrop. Competitive ratio of 1 means the performance of species " $a$ " and " $b$ " is the same, greater than 1 means the performance of species " $a$ " is better than that of species "b," while less than 1 means the performance of species " $b$ " is better than that of species "a."

2.7. Statistical Analysis. Analysis of variance in the RCBD model was used to determine whether statistical differences exist among the accessions, the cropping system, the different years, and the interactions in each case of the three indicated. Multiple mean comparison was used when a probability of $P \leq 0.05$ occurred using a least significant difference at $5 \%$.

\section{Results}

3.1. Growth and Yield Performance of Roselle Accessions due to Intercropping. The results showed that intercropping generally resulted in significantly higher calyx and shoot dry yields, total aboveground dry biomass yield, and thousand seed weight compared to sole cropping (Table 3 ). Local had the highest values in all growth and yield attributes assessed. Bissap had the lowest values for number of leaves per plant, stem diameter, calyx fresh and dry yields, shoot dry yield, and total aboveground dry biomass (Table 3 ).

The effect of cropping system on calyx fresh and dry yields, shoot dry yield, and thousand seed weight was influenced by the growing season. Also, variation in thousand seed weight among the accessions due to the cropping system was also dependent on the cropping season (Table 4). 
TABLE 3: Main effect of accession and cropping system on roselle growth and yield performance.

\begin{tabular}{lccccccccc}
\hline & NL & PH & SD & CDY & CYF & CFY & SDY & TDB & TSW \\
\hline Accession & & & & & & & & \\
A1 & $120.00 \mathrm{a}$ & $62.80 \mathrm{~b}$ & $0.22 \mathrm{a}$ & $0.23 \mathrm{a}$ & $9.32 \mathrm{bc}$ & $1.77 \mathrm{a}$ & $2.35 \mathrm{a}$ & $3.02 \mathrm{a}$ & $18.80 \mathrm{ab}$ \\
A2 & $185.40 \mathrm{bc}$ & $85.40 \mathrm{c}$ & $1.53 \mathrm{~b}$ & $0.48 \mathrm{~b}$ & $9.91 \mathrm{~b}$ & $3.53 \mathrm{~b}$ & $3.89 \mathrm{bc}$ & 5.34 & $21.91 \mathrm{~b}$ \\
A3 & $155.40 \mathrm{~b}$ & $49.90 \mathrm{a}$ & $1.61 \mathrm{~b}$ & $0.27 \mathrm{a}$ & $6.17 \mathrm{a}$ & $2.28 \mathrm{a}$ & $3.63 \mathrm{~b}$ & $4.57 \mathrm{~b}$ & $16.48 \mathrm{a}$ \\
\hline Cropping system & & & & & & & & & \\
IC & $150.70 \mathrm{a}$ & $66.70 \mathrm{a}$ & $1.44 \mathrm{a}$ & $0.37 \mathrm{~b}$ & $8.18 \mathrm{a}$ & $2.67 \mathrm{a}$ & $3.64 \mathrm{~b}$ & $4.81 \mathrm{~b}$ & $22.78 \mathrm{~b}$ \\
S & $156.60 \mathrm{a}$ & $65.40 \mathrm{a}$ & $1.46 \mathrm{a}$ & $0.28 \mathrm{a}$ & $8.75 \mathrm{a}$ & $2.39 \mathrm{a}$ & $2.94 \mathrm{a}$ & $3.81 \mathrm{a}$ & $15.35 \mathrm{a}$ \\
LSD & $\mathrm{ns}$ & $\mathrm{ns}$ & $\mathrm{ns}$ & 0.06 & $\mathrm{~ns}$ & $\mathrm{~ns}$ & 0.57 & 0.79 & 2.81 \\
\hline
\end{tabular}

A1 = Bissap; A2 = Local; A3 = Samadah; IC = intercrop; S = sole; CDY = calyx dry yield (t/ha); CYF = calyx yield fraction (\%); CFY = calyx fresh yield (t/ha); $\mathrm{SDY}=$ shoot dry yield $(\mathrm{t} / \mathrm{ha}), \mathrm{NL}=$ number of leaves per plant $(n) ; \mathrm{PH}=$ plant height $(\mathrm{cm}) ; \mathrm{SD}=$ stem diameter $(\mathrm{cm}) ; \mathrm{TDB}=$ total aboveground dry biomass $(\mathrm{t} / \mathrm{ha}) ; \mathrm{TSW}=$ thousand seed weight $(\mathrm{g}) ; \mathrm{LSD}=$ least significant difference; $\mathrm{ns}=$ not significant.

The 2017 cropping season generally resulted in higher values for both intercropping and sole cropping systems except for thousand seed weight. There were significantly higher values for number of leaves per plant, stem diameter, calyx fresh and dry yields, and calyx yield fraction in 2017 than in the 2016 cropping season. Total aboveground dry biomass yield was however higher for both intercrop and sole crop systems in 2016 than in the 2017 cropping season. It was realized that thousand seed weight was highest for Local in the intercropping system for the 2016 cropping season and Bissap in the sole cropping system for the 2017 cropping season (Table 4).

The accession Bissap obtained lower values in number of leaves per plant, plant height, stem diameter, calyx fresh and dry yields, and calyx yield fraction but higher values in total aboveground dry biomass in 2016 than in the 2017 cropping season. The accession Local had higher values in number of leaves per plant, plant height, and total aboveground dry biomass but lower values in stem diameter, calyx fresh yield, and calyx yield fraction in 2016 than in the 2017 cropping season. However, Samadah was higher only in number of leaves per plant but lower in all the other growth and yield attributes in 2016 than in the 2017 cropping season (Table 4). There were no significant differences in the three-way interaction between accessions, cropping system, and season except for thousand seed weight.

3.2. Growth and Yield of Maize in Intercrop, Sole, and Season. The analysis of variance results showed that maize growth and yield attributes were not significantly different between intercropping and sole cropping systems for any of the cropping seasons (Table 5). However, there was significant $(P<0.05)$ general seasonal variation in grain yield, cob yield, hundred seed weight, grain yield fraction, and stalk yield but not growth attributes (data not shown).

3.3. Intercrop Performance of Roselle. There were no significant differences among the accessions for area $\times$ time equivalence and competitive ratios (Table 6). However, there was seasonal variation of the accessions in their ATER, whereas Local recorded the highest ATER in 2016 and Samadah recorded the highest value in 2017 (Figure 1). All roselle accessions had ATER values more than one, the
TABLE 4: Seasonal variation in intercrop and accessions' performance.

\begin{tabular}{|c|c|c|c|c|c|c|}
\hline & NL & CFY & $\mathrm{CDY}$ & SDY & CYF & TDB \\
\hline \multicolumn{7}{|c|}{ Cropping system $\times$ season } \\
\hline IC $\times$ '16 & 148.30 & 1.89 & 0.33 & 3.38 & 6.30 & 5.28 \\
\hline IC $\times ’ 17$ & 153.10 & 3.46 & 0.40 & 3.91 & 10.07 & 4.33 \\
\hline$S \times ' 16$ & 145.70 & 1.50 & 0.19 & 3.34 & 4.44 & 4.73 \\
\hline$S \times ' 17$ & 167.40 & 3.28 & 0.38 & 2.53 & 13.06 & 2.89 \\
\hline LSD (0.05) & 36.5 & 0.74 & 0.08 & 0.81 & 2.32 & 1.11 \\
\hline \multicolumn{7}{|c|}{ Accession $\times$ season } \\
\hline A1 $\times ' 16$ & 86.80 & 1.50 & 0.25 & 2.93 & 6.37 & 4.03 \\
\hline $\mathrm{A} 1 \times{ }^{\prime} 17$ & 153.20 & 2.05 & 0.22 & 1.77 & 12.28 & 2.00 \\
\hline A $2 \times ' 16$ & 189.50 & 2.40 & 0.40 & 4.17 & 6.22 & 6.55 \\
\hline A $2 \times ' 17$ & 181.40 & 4.67 & 0.55 & 3.62 & 13.60 & 4.13 \\
\hline A $3 \times ' 16$ & 164.70 & 1.18 & 0.13 & 2.98 & 3.53 & 4.43 \\
\hline A $3 \times ’ 17$ & 146.10 & 3.38 & 0.40 & 4.28 & 8.80 & 4.70 \\
\hline LSD (0.05) & 44.7 & 0.9 & 0.10 & 0.99 & 2.85 & 1.36 \\
\hline
\end{tabular}

A1 = Bissap; A2 = Local; A3 = Samadah; IC = intercrop; S = sole; '16 and '17 are the cropping seasons in 2016 and 2017, respectively; $\mathrm{NL}=$ number of leaves per plant; $\mathrm{CDY}=$ calyx dry yield $(\mathrm{t} / \mathrm{ha}) ; \mathrm{SDY}=$ shoot dry yield $(\mathrm{t} / \mathrm{ha})$; $\mathrm{CYF}=$ calyx yield fraction $(\%) ; \mathrm{CFY}=$ calyx fresh yield $(\mathrm{t} / \mathrm{ha}) ; \mathrm{TDB}=$ total aboveground dry biomass ( $\mathrm{t} / \mathrm{ha}) ; \mathrm{LSD}=$ least significant difference.

lowest being 1.99 obtained by Samadah (A3) and the highest being 2.49 obtained by Local (A2). Thus, it could be seen that, in intercropping Local with maize, one could save up to $56 \%$ of land compared to when it is cropped as sole. The competitive ratios ranged from 1.03 to 1.17 for stem diameter, 1.12 to 1.25 for plant height, and 0.96 to 1.09 for number of leaves per plant.

\section{Discussion}

4.1. Intercropping Effect on Growth and Yield Attributes of Roselle. Differences in roselle growth and yield attributes observed between the two seasons could be due to differences in sowing date between both years. It has been shown that planting date affects the growth and yield of roselle [16]. Also, there were differences in precipitation between the years. However, the emphasis of this study was to observe the interspecific interaction between the two crops within each year. Genotypic variability existed among the roselle accessions assessed for both growth and yield attributes which is in conformity with previous studies $[17,18]$. It was realized that Local which has green calyces is a potential 
TABLE 5: Maize growth and yield attributes in response to intercropping with roselle accessions and season.

\begin{tabular}{|c|c|c|c|c|c|c|c|c|c|c|c|}
\hline & NL & $\mathrm{PH}$ & $\mathrm{SD}$ & GM & GYF & GY & $\mathrm{HY}$ & HSW & $\mathrm{CW}$ & SY & TDB \\
\hline \multicolumn{12}{|c|}{ Cropping system } \\
\hline MA1 & 10.43 & 127.90 & 1.23 & 22.10 & 48.17 & 2.52 & 0.48 & 23.53 & 2.77 & 1.77 & 5.03 \\
\hline MA2 & 10.42 & 117.40 & 1.23 & 24.08 & 49.78 & 2.48 & 0.40 & 24.38 & 2.78 & 1.85 & 5.02 \\
\hline MA3 & 10.23 & 118.80 & 1.18 & 25.42 & 46.83 & 2.35 & 0.47 & 21.62 & 2.73 & 1.65 & 4.83 \\
\hline SM & 10.80 & 135.10 & 1.29 & 24.75 & 48.33 & 2.58 & 0.53 & 26.02 & 2.97 & 1.78 & 5.27 \\
\hline LSD & ns & $\mathrm{ns}$ & ns & ns & ns & ns & ns & ns & ns & ns & ns \\
\hline \multicolumn{12}{|c|}{ Cropping system $\times$ season } \\
\hline MA1 $\times ' 16$ & 11.00 & 129.80 & 1.33 & 18.03 & 42.53 & 1.70 & 0.30 & 16.33 & 1.73 & 1.83 & 3.87 \\
\hline MA $1 \times ' 17$ & 9.87 & 125.90 & 1.13 & 26.17 & 53.80 & 3.33 & 0.67 & 30.73 & 3.80 & 1.70 & 6.20 \\
\hline MA $2 \times ' 16$ & 10.67 & 113.20 & 1.26 & 22.73 & 44.07 & 2.20 & 0.27 & 16.33 & 2.40 & 2.43 & 5.07 \\
\hline MA2 $\times$ '17 & 10.17 & 121.60 & 1.20 & 25.43 & 55.50 & 2.77 & 0.53 & 32.43 & 3.17 & 1.27 & 4.97 \\
\hline MA3 $\times ' 16$ & 10.00 & 109.40 & 1.16 & 24.00 & 38.03 & 1.40 & 0.27 & 15.67 & 1.60 & 1.83 & 3.70 \\
\hline MA3 $\times$ ' 17 & 10.47 & 128.30 & 1.20 & 26.83 & 55.63 & 3.30 & 0.67 & 27.57 & 3.87 & 1.47 & 5.97 \\
\hline SM ×'16 & 11.33 & 147.80 & 1.31 & 20.83 & 44.40 & 1.90 & 0.33 & 16.33 & 2.03 & 1.90 & 4.27 \\
\hline $\mathrm{SM} \times{ }^{\prime} 17$ & 10.27 & 122.40 & 1.27 & 28.67 & 52.27 & 3.27 & 0.73 & 35.70 & 3.90 & 1.67 & 6.27 \\
\hline LSD & ns & ns & ns & ns & ns & ns & ns & ns & ns & ns & ns \\
\hline
\end{tabular}

MA1 = maize intercropped with Bissap; MA2 = maize intercropped with Local; MA3 = maize intercropped with Samadah; SM=sole maize; GM= grain moisture at harvest (\%); GYF = grain yield fraction (\%); GY = grain yield ( $\mathrm{t} / \mathrm{ha}) ; \mathrm{HY}=$ husk yield (t/ha); $\mathrm{NL}=$ number of leaves per plant; $\mathrm{PH}=$ plant height $(\mathrm{cm}) ; \mathrm{SD}=$ stem diameter $(\mathrm{cm})$; HSW = hundred seed weight $(\mathrm{g}) ; \mathrm{CW}=$ cob weight $(\mathrm{t} / \mathrm{ha}) ; \mathrm{SY}=$ stalk yield $(\mathrm{t} / \mathrm{ha}) ; \mathrm{TDB}=$ total aboveground dry biomass $(\mathrm{t} / \mathrm{ha})$; $\mathrm{LSD}=$ least significant difference; ns = not significant.

TABLE 6: Intercrop performance of roselle yield and growth attributes.

\begin{tabular}{|c|c|c|c|c|c|}
\hline & ATER & PLS & CRSD & $\mathrm{CRPH}$ & CRNL \\
\hline \multicolumn{6}{|l|}{ Accession } \\
\hline A1 & 2.18 & 52.2 & 1.06 & 1.12 & 0.96 \\
\hline $\mathrm{A} 2$ & 2.49 & 56.9 & 1.17 & 1.21 & 1.09 \\
\hline $\mathrm{A} 3$ & 1.99 & 48.0 & 1.03 & 1.25 & 1.03 \\
\hline LSD & ns & ns & $\mathrm{ns}$ & ns & ns \\
\hline \multicolumn{6}{|c|}{ Accession $\times$ season } \\
\hline A1 ×'16 & \multirow{7}{*}{$\begin{array}{c}\text { See } \\
\text { Figure } 1\end{array}$} & \multirow{7}{*}{$\begin{array}{c}\text { See } \\
\text { Figure } 1\end{array}$} & 1.13 & 1.24 & 0.99 \\
\hline A1 $\times ' 17$ & & & 0.99 & 0.99 & 0.93 \\
\hline $\mathrm{A} 2 \times ' 16$ & & & 1.07 & 1.31 & 1.20 \\
\hline A $2 \times ' 17$ & & & 1.26 & 1.11 & 0.98 \\
\hline A3 $\times ' 16$ & & & 1.02 & 1.47 & 1.18 \\
\hline A $3 \times{ }^{\prime} 17$ & & & 1.04 & 1.03 & 0.88 \\
\hline LSD & & & ns & ns & ns \\
\hline
\end{tabular}

A1 = Bissap; A2 = Local; A3 = Samadah;' '16 and '17 are the cropping seasons in 2016 and 2017; ATER $=$ area $\times$ time equivalence ratio; PLS $=$ percentage land saved; $\mathrm{CRPH}=$ competitive ratio for plant height; $\mathrm{CRSD}=$ competitive ratio for stem diameter; $\mathrm{CRNL}=$ competitive ratio for number of leaves; $\mathrm{LSD}=$ least significant difference; $\mathrm{ns}=$ not significant .

good accession that could be promoted due to its performance both as sole and in intercrop. Both leaves and calyces of this accession are ideal for the preparation of soups.

Area $\times$ time equivalence ratio differed between the seasons. This could be due to the differences in sowing date and weather conditions which can affect the performance of roselle [16]. Intercropping roselle with maize has proven to result in yield benefit to roselle. This has not always been the case. It has been shown that yield losses occur in roselle when intercropped with other crops. For instance, Fbabatunde [19] revealed that roselle yields were more reduced when intercropped with cereals such as millet and sorghum than intercropping with legumes. In maize-legume intercrops, it was realized that maize reduced cowpea yields more than the effect of cowpea on maize yields because of

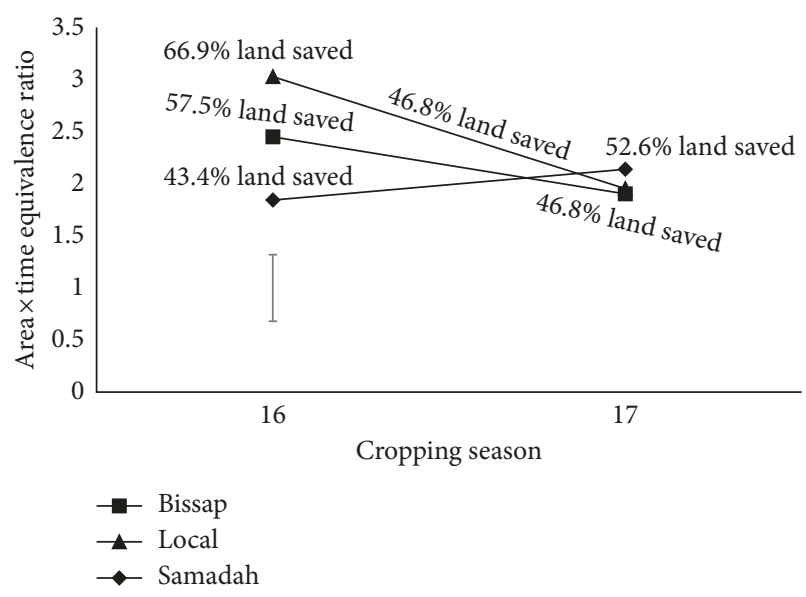

FIGURE 1: Intercrop performance of roselle accessions. Vertical bar represents the least significant difference.

greater competitive ability of maize when intercropped with cowpea [20]. In our study however, intercropping roselle with maize was not inimical to roselle. Intercropping did not affect growth attributes of roselle in our case and even resulted in higher yield than the sole cropping. The current finding is a revelation that intercropping roselle with maize could offer a sustainable way of producing roselle especially for calyx and shoot yield. Calyx and shoot dry yields are among the most important economic components of the roselle plant. This is because in Ghana for instance, the reddish calyx types are used in the preparation of a refreshing drink called sobolo, whereas the greenish calyx types are used in the preparation of soups. In traditional domestic homes of northern Ghana where fuel for cooking is scarce, dry shoots of roselle serve as a good source of fuel for domestic purposes. Thus, a significant increase in roselle calyx and shoot dry yields due to intercropping implies that intercropping could be harnessed to increase the productivity 
of roselle in the Guinea savannah ecology of Ghana whose cropping system is predominantly cereal based. There was no variability in the response of the accessions to intercropping. This means that intercropping was generally advantageous irrespective of accession. This conforms the conclusion drawn by Ijojah [21] who after reviewing different intercropping studies between maize and various vegetables indicated that cereal-vegetable intercrops are highly complementary.

4.2. Intercropping Effect on Growth and Yield Attributes of Maize. A nonsignificant effect of intercropping roselle with maize was realized in our study. This could be due to the fact that roselle as a $\mathrm{C}_{3}$ crop [22] would compete less with maize which is a $\mathrm{C}_{4}$ crop for incoming radiation. Also, roselle has a deeper root system than maize, thereby competing less with maize for water and nutrients. Therefore, it could be concluded that species complementarity exists between maize and roselle. That is, roselle can be conveniently intercropped with maize without any detrimental effects on the maize growth and yield attributes, and vice versa. This is not always the case in intercropping trials between maize and other vegetables. In some cases, maize yields were reduced upon intercropping with vegetables $[23,24]$. Thus, not just the system of cultivation, but the test crop type may also affect the yield of any of the two crop species in an intercrop system. Intercropped maize was negatively affected by intercropping with wheat, especially during its early growth for a lower leaf appearance rate [25] and a lower biomass accumulation per day [26]. Depending on the vegetable, intercropping maize with vegetables can result in higher gains as reported for intercropping hybrid maize with different short-duration vegetables [24], intercropping winter maize with vegetables [23], and intercropping maize with different vegetables [27] or no effect as shown by our study (Table 5).

4.3. Intercrop Productivity of Roselle. In all intercropping systems studied, ATER values were more than one, indicating a better utilization of space and time. Competitive ability of the roselle accessions except Bissap was comparable with that of maize. Adhikary [28] found that productivity of vegetables reduced as a result of higher competitive ability of the baby corn. Also, the high ATER recorded by the roselle in this study could be due to the potential of intercrops to intercept higher incoming solar radiation. Kanton and Dennett [9] found that intercrops intercepted more incoming solar radiation resulting in higher biomass production of the intercrops than the sole crops. Zhu [29] found that, in all wheat-maize intercropping studies, intercropped wheat always showed yield advantage compared to sole wheat. The roselle accessions possibly portrayed characteristics such as branching habit and leaf angle that are indicative of a good intercrop.

\section{Conclusion}

Generally, intercropping did not affect the growth attributes of the roselle accessions studied nor did it affect maize growth and yield attributes. The yield of roselle was however greatly increased upon intercropping with maize due to the complementary effect between the two species. Local outperformed the other two accessions both as sole and in intercrop. Hence, when intercropping roselle with maize, a farmer should consider Local.

Intercropping roselle with maize gave a very productive use of land and time shown by area $\times$ time equivalence ratio of more than unity, and thus, intercropping the roselle accessions with maize is quite sustainable.

\section{Data Availability}

The data used to support the findings of this study are available from the corresponding author upon request.

\section{Conflicts of Interest}

The authors declare that they have no conflicts of interest.

\section{Authors' Contributions}

EA conceptualized the idea and wrote the manuscript, MA and RYA supervised the work and edited the manuscript, DAA and SKB collected the data, and DAA used some of the data for her BSc thesis.

\section{References}

[1] R. S. McCaleb, Hibiscus Production Manual, S.l.: s.n, Herb Research Foundation, Boulder, CO, USA, 1998.

[2] S. Atta, A. B. Diallo, B. Sarr, Y. Bakasso, M. Saadou, and R. H. Glew, "Variation in macro-elements and protein contents of Roselle (Hibiscus sabdariffa L.) from Niger," African Journal Food, Agriculture Nutrition and Development, vol. 10, pp. 2707-2718, 2010.

[3] N. Mahadevan, Shivali, and K. Pradeep, "Hibiscus sabdariffa Linn.-an overview," Natural Product Radiance, vol. 8, pp. 77-83, 2009.

[4] A. Mungole and A. Chaturvedi, "Hibiscus sabdariffa L. a rich source of secondary metabolites," International Journal of Pharmaceutical Sciences, Review and Research, vol. 6, no. 1, pp. 83-87, 2011.

[5] R. Mohammed, J. Fernandez, M. Pineda, and M. Aguilar, "Roselle (Hibiscus sabdariffa) seed oil is a rich source of a-tocopherol," Journal of Food Science, vol. 72, no. 3, pp. s207-s211, 2007.

[6] N. Mohd-Esa, F. S. Hern, A. Ismail, and C. L. Yee, "Antioxidant activity in different parts of roselle (Hibiscus sabdariffa L.) extracts and potential exploitation of the seeds," Food Chemistry, vol. 122, no. 4, pp. 1055-1060, 2010.

[7] M. Modi, A. T. Modi, and S. Hendriks, "Potential role for wild vegetables in household food security: a preliminary case study in KwaZulu-Natal, South Africa," African Journal of Food Agriculture Nutrition and Development, vol. 6, no. 1, 2006.

[8] D. Harris, M. Natarajan, and R. W. Willey, "Physiological basis for yield advantage in a sorghum/groundnut intercrop exposed to drought. 1. Dry-matter production, production, yield and light interception," Field Crops Research, vol. 17, no. 3-4, pp. 259-272, 1987.

[9] R. A. L. Kanton and M. D. Dennett, "Radiation capture and use as affected by morphologically contrasting maize/pea in 
sole and intercropping," West African Journal of Applied Ecology, vol. 13, no. 1, 2008.

[10] F. D. Li, P. Meng, D. L. Fu, and B. P. Wang, "Light distribution, photosynthetic rate and yield in a Paulownia-wheat intercropping system in China," Agroforestry System, vol. 74, no. 2, pp. 163-172, 2008.

[11] P. E. Odo and K. N. Futuless, "Millet soyabean intercropping as affected by different sowing dates of soyabean in a semi-arid environment," Cereal Research Community, vol. 28, pp. 153-160, 2002.

[12] B. C. Blaser, J. W. Singer, and L. R. Gibson, "Winter cereal, seeding rate and intercrop seeding rate effect on red clover yield and quality," Agronomy Journal, vol. 99, no. 3, pp. 723-729, 2007.

[13] M. A. Musah, I. I. Y. Baba, W. Dogbe, M. Abudulai, A. Mutari, and M. Haruna, "NERICA intercrop systems and their influence on yield components and productivity of NERICA and partner crops in the Guinea Savannah Zone of Ghana," International Journal of AgriScience, vol. 3, p. 12, 2013.

[14] SARI, Annual Report of Savanna Agriculture Research Institute, SARI, Nyankpala, Ghana, 2008.

[15] M. S. Abdulai, S. S. J. Buah, R. Y. Agyare, E. Ayipio, and S. K. Bonsu, "Enhancing productivity, competitiveness and marketing of Traditional African (Leafy) vegetables for improved income and nutrition in West and Central Africa (TAVs for Income and Nutrition)," in CSIR-SARI Annual Report, S. S. J. Buah, S. K. Nutsugah, M. Abudulai, W. N. Kutah, and R. K. Owusu, Eds., pp. 85-86, SARI Nyankpala, Ghana, 2015.

[16] K. Abdul Mateen, S. Muhammad, Z. S. Hamid, R. Abdur, A. Masood, and A. K. Muhammad, "Effect of Sowing Time and Plant Density on the Growth and Production of Roselle (Hibiscus sabdariffa)," International Journal of Agriculture \& Biology, pp. 1814-9596, 2016.

[17] S. M. Gasim and M. O. Khidir, "Genetic variability of some characters in roselle (Hibiscus sabdariffa var sabdariffa)," Journal of Agricultural Sciences, vol. 6, pp. 22-34, 1998.

[18] S. Atta, H. H. Seyni, Y. Bakasso, B. Sarr, I. Lona, and M. Saadou, "Yield character variability in Roselle (Hibiscus sabdariffa L.)," African Journal of Agricultural Research, vol. 6, no. 6, pp. 1371-1377, 2011.

[19] F. E. Fbabatunde, "Intercrop productivity of roselle in Nigeria," African Crop Science Journal, vol. 11, no. 1, pp. 43-48, 2003.

[20] F. Ofori and W. R. Stern, "Relative sowing time and density of component crops in a maize/cowpea intercrop system," $E x$ perimental Agriculture, vol. 23, pp. 41-52, 1987.

[21] M. O. Ijoyah, "Review of intercropping research: Studies on cereal-vegetable based cropping system," Scientific Journal of Crop Science, vol. 1, no. 3, 2012.

[22] B. A. Sonar, "Physiological studies in salt tolerance of three species of Hibiscus (H. cannabinus Linn. H. sabdariffa Linn. and H. tiliaceus Linn.)," Ph. D. thesis, Shivaji University, Kolhapur, India, 2013.

[23] S. K. Choudhary, R. N. Singh, R. K. Singh, and P. K. Upadhyay, "Yield and nutrient uptake of winter maize (Zea mays) with vegetable intercropping," Current Advances in Agricultural Sciences, vol. 6, no. 1, 2014.

[24] M. A. Rahaman, M. M. Rahman, S. Roy, M. Ahmed, and M. S. Bhuyan, "On-farm study on intercropping of hybrid maize with different short duration vegetables in the Charland of Tangail," Bangladesh Agronomy Journal, vol. 18, no. 2, p. 65, 2015.
[25] J. Zhu, J. Vos, W. Van der Werf, P. E. Van der Putten, and J. B. Evers, "Early competition shapes maize whole-plant development in mixed stands," Journal of Experimental Botany, vol. 65, no. 2, pp. 641-653, 2014.

[26] L. Li, J. Sun, F. Zhang, X. Li, S. Yang, and Z. Rengel, "Wheat/ maize or wheat/soybean strip intercropping. Yield advantage and interspecific interactions on nutrients," Field Crops Research, vol. 71, no. 2, pp. 123-137, 2001.

[27] M. R. Ali, M. S. Rahman, M. Asaduzzaman, M. M. Hossain, and M. A. Mannan, "Intercropping maize with different vegetables," Bangladesh Agronomy Journal, vol. 18, no. 1, p. 49, 2015.

[28] S. Adhikary, M. K. Pandit, A. V. V. Koundinya, S. Bairagi, and A. Das, "Examination of system productivity and profitability of baby corn based vegetable intercropping systems," Journal of Crop and Weed, vol. 11, no. 1, 2015.

[29] J. Zhu, W. Van der Werf, J. Vos, N. P. R. Anten, P. E. L. Van der Putten, and J. B. Evers, "High productivity of wheat intercropped with maize is associated with plant architectural responses," Annals of Applied Biology, vol. 168, no. 3, pp. 357-372, 2016. 


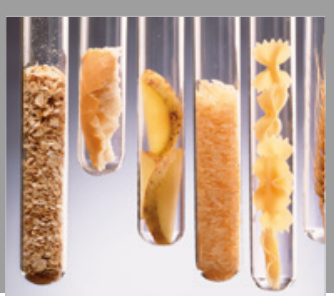

International Journal of Food Science

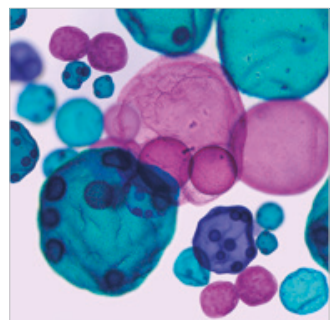

International Journal of Microbiology
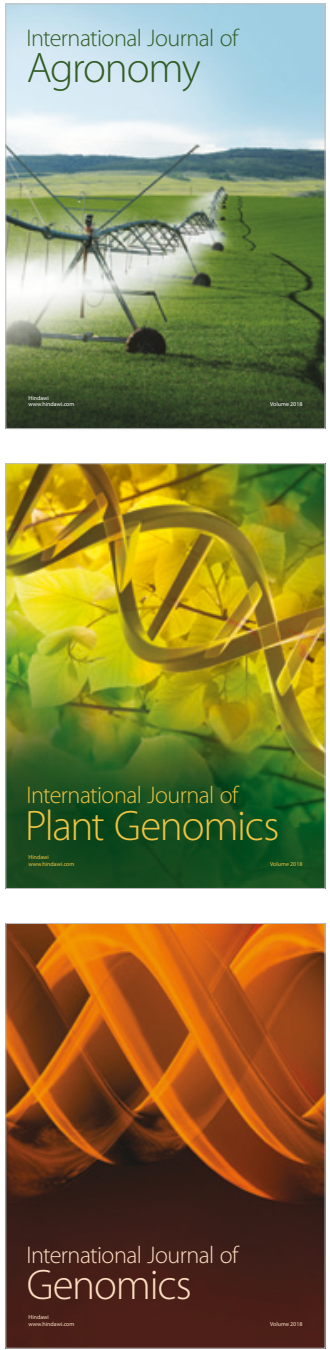

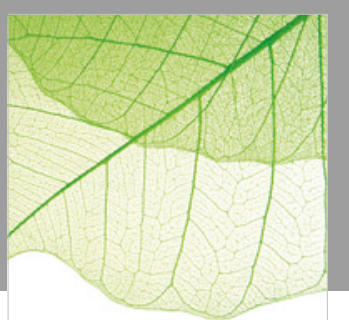

Journal of Botany
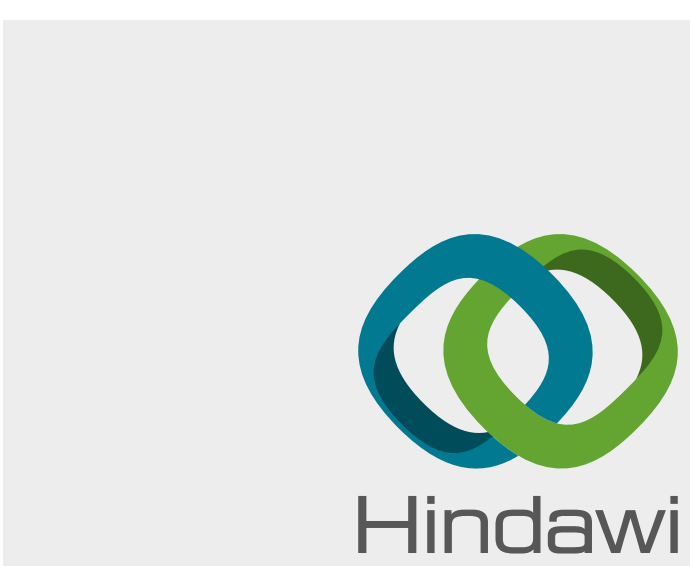

Submit your manuscripts at

www.hindawi.com
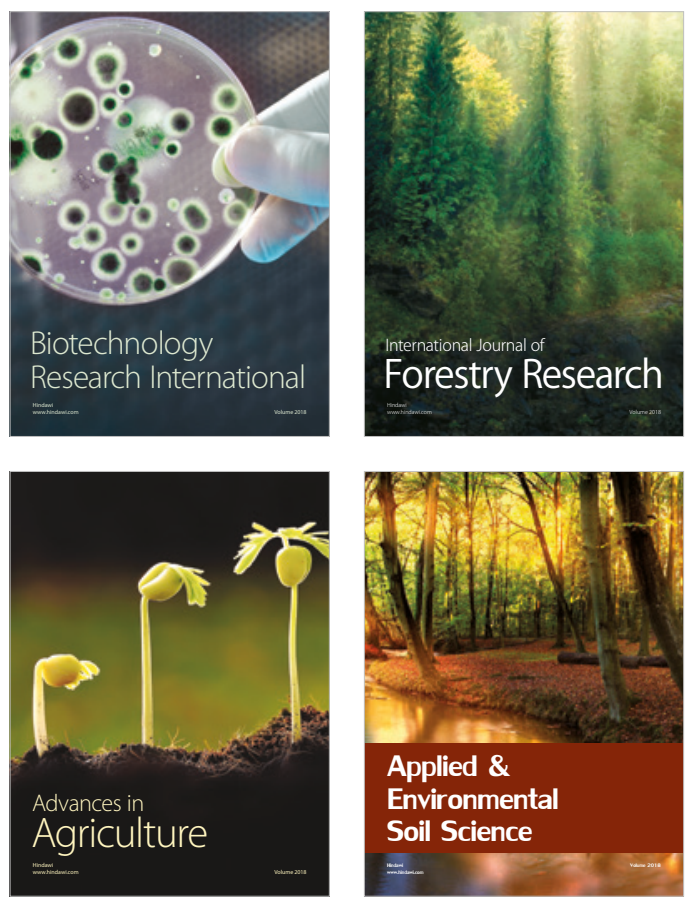

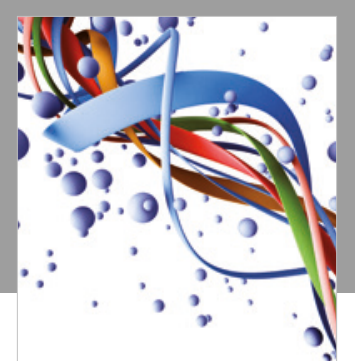

Scientifica

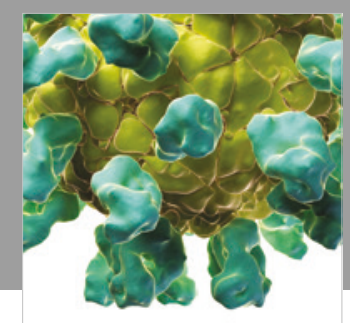

Veterinary Medicine International

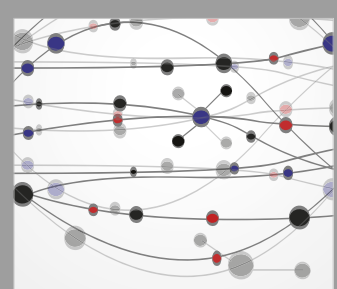

The Scientific World Journal
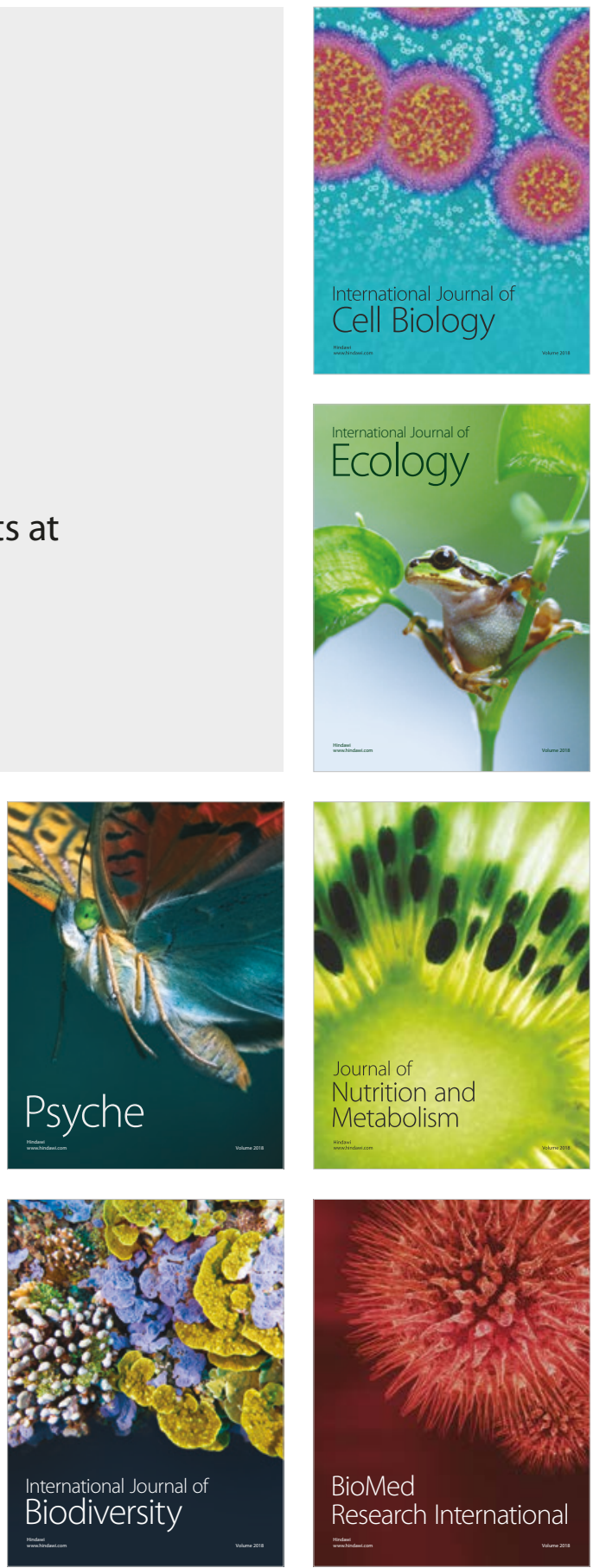